\title{
TRYGGER ELDRE SOM SKRIVES UT AV SYKEHUS
}

\section{Trygt hjem. Å utvikle tverrfaglige hjelpemidler på}

tvers av etater er nødvendig for å øke pasientsikkerheten

for eldre i overgangen mellom sykehus og kommune.

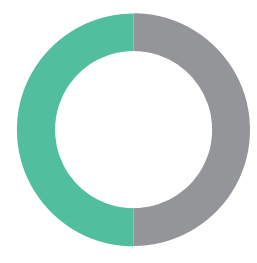

DOI-NUMMER:

10.4220/Sykepleiens.2015.54980

Anne

Kvalheim,

spesialrådgiver/

sosialantropo-

log, Haukeland

universitets-

sjukehus

Åshild

Bjørnethun,

fagutviklings-

sykepleier,

Haukeland

universitets-

sjukehus

Trond Eirik

Bergflødt,

sykepleiefaglig

konsulent, Ber-

gen kommune

Tone Elin

Mekki,

førsteamanuen-

sis, Høgskolen i

Bergen

Oddvar

Førland,

førsteamanuen-

sis, Høgskolen

i Bergen og

Haraldsplass

diakonale

høgskole

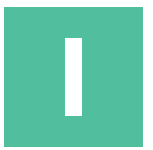

nn- og utskrivning mellom hjemmet og sykehus er en sår-

bar og krevende fase både for den eldre selv, pårørende og for helsepersonell. For den eldre kan fasen være forbundet med bekymringer knyttet til sykdom og helse, endringer i livs- eller bosituasjon og økt avhengighet av helsepersonell og pårørende. For pårørende innebærer fasen ofte utvidete plikter, mer praktisk innsats og nye utfordringer i samarbeidet mellom familiemedlemmer og det offentlige hjelpeapparatet. For helsepersonell innebærer overflyttingen utfordringer knyttet til vurdering av den eldres helse, sosiale situasjon og riktig omsorgsnivå. I tillegg kommer samarbeid med pårørende og annet helsepersonell på ulikt nivå av helsetjenesten.

MANGELFULL. Forskning har vist at informasjonsutvekslingen mellom sykehus og kommune ofte er mangelfull $(1,2)$ og at det er økt risiko for at feil oppstår når pasienter overflyttes mellom tjenestenivåene (3 4). I denne artikkelen oppsummerer vi erfaringer fra 2007 og fram til i dag fra et prosjekt som har hatt slike utfordringer som utgangspunkt. Disse er blitt aktualisert gjennom samhandlingsreformen og er berørt i flere offentlige utredninger og meldinger de siste årene (5-10). Andre kommuner og sykehus kan dra nytte av erfaringene fra prosjektet i Bergen.

TRYGG OVERFøRING. Prosjektet "Trygg overføring» hadde sitt utspring i Medisinsk avdeling ved Haukeland universitetssjukehus i 2007. Ansatte ved postene opplevde det belastende å forholde seg til sykehusinterne forventninger om høy pasientgjennomstrømming, og samarbeidet mellom tje-

\section{«Ved at begge parter bruker sjekklistene får man hjelp til å væere forberedt og strukturert i samtalen.»}

nestenivåene var preget av mangler og svikt fra begge parter. Til tider kunne kontakten mellom sykehusansatte og ansatte i kommunen bli amper og preget av manglende forståelse og respekt.

I prosjektets første fase (20072009) kartla man eksisterende praksis når det gjaldt overføring av pasienter mellom en medisinsk sykehusavdeling og Årstad bydel i Bergen kommune.

FUNN. Sykepleierne koordinerer vanligvis kontakten mellom sykehuset og kommunenes pleie- og omsorgstjeneste. Det var derfor viktig å kartlegge og analysere deres rolle og samhandling i forbindelse med utskriving av eldre pasienter. For å avdekke gjeldende praksis ble det utført fokusgruppeintervjuer med ansatte på medisinske poster ved sykehuset, i hjemmetjenestene og ved forvaltningsenheten i kommunen. I tillegg ble det gjort journalgransking i pasientjournalene til 67 eldre pasienter.

Undersøkelsene konkluderte med flere utfordringer i samhandlingen mellom hjemmetjenestene og sykehusavdelingene (11):

- Ulike vurderinger av pasientenes behov og funksjonsnivå.

- Ineffektive kommunikasjonslinjer.

- Mangelfull samhandling om søknads- og behandlingsprosesser i forbindelse med oppfølgingstilbudet i kommunene etter endt sykehusopphold.

- Tilspissing mot helg, med økt utskrivningsaktivitet fra sykehuset og kapasitetsproblemer i kommunen. Pårørende risikerte
Fakta $\bullet$

Hoved-

budiskap:

Faglige hjelpemidler som guider helsepersonell og understøtter ønsket praksis er nødvendig for å skape trygghet når eldre pasienter legges inn i sykehus og skrives ut til hjem eller sykehjem.

Nøkkelord

Les mer og finn litteraturhenvisninger på våre nettsider

- Samhanling

- Trygghet

- Eldre

- Spesialisthelse-

tjeneste

- Kommunehelsetjeneste 


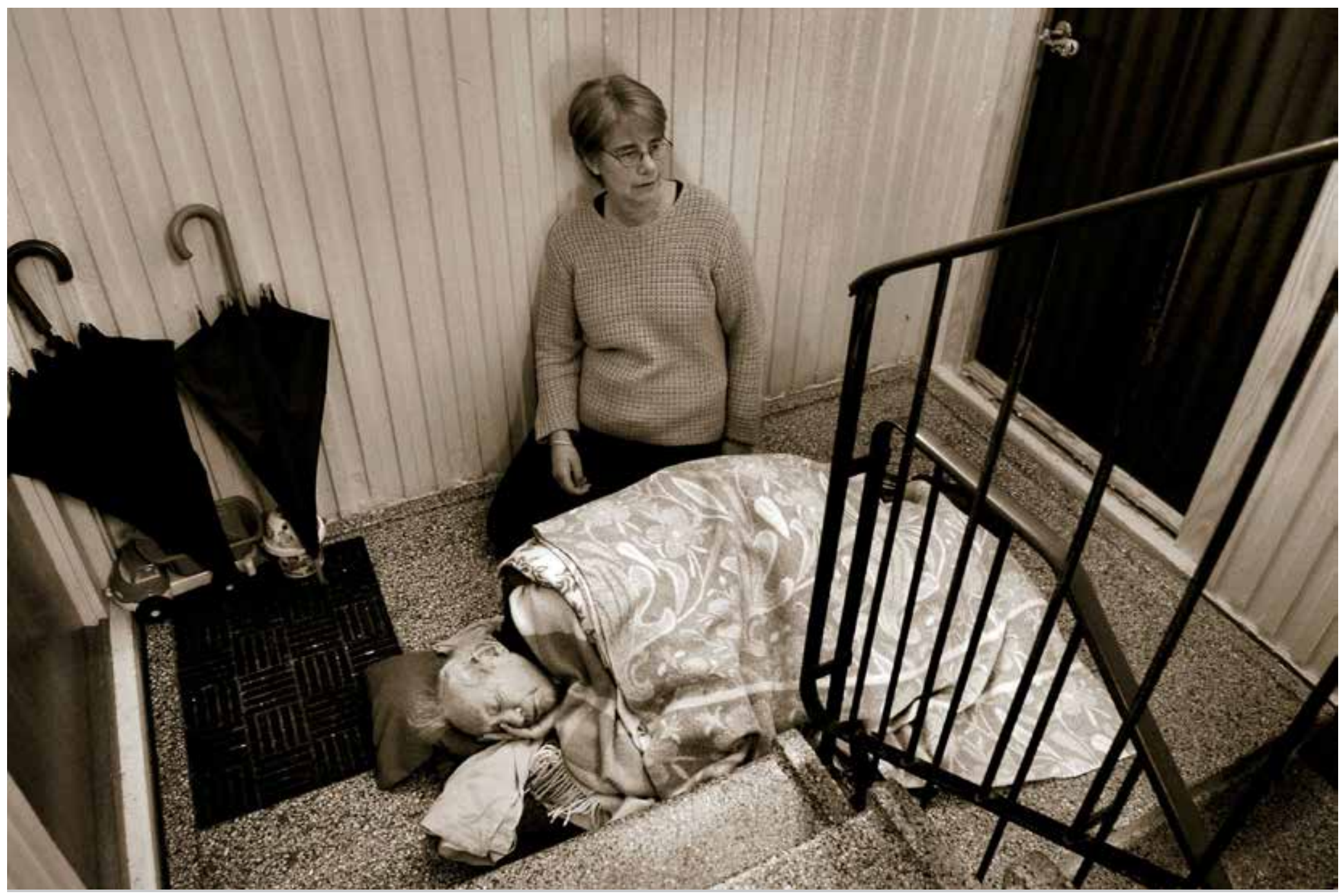

Årets bilde 2006: Dette bildet med tittelen «Verdens rikeste land?» av Bjarne Nilsen i Fyllingsdalen i Bergen ble kåret til årets bilde i 2006. Etter en uke på sykehus ble Nilsen sendt hjem i drosje, men siden han ikke kan gå selv på grunn av hofteproblemer ble han liggende i gangen i to timer, ute av stand til å nå leiligheten sin i tredje etasje. Først da ambulansepersonell kom to timer senere fikk han hjelp til å komme seg inn til seg selv. Foto: Morten Wanvik

å bli stående med oppfølgingsansvaret fredag ettermiddag («den farlige fredagen»).

- Kontakten mellom tjenestenivåene baserte seg på sporadiske og til tider ustrukturerte telefonsamtaler, der helhetsbildet av pasientens status og forventet utvikling ble ulikt vurdert og formidlet.

NYE TILTAK. Med bakgrunn i disse funnene ble det i prosjektets andre fase (2009-2011) utviklet nye tiltak for å støtte samhandlingen mellom sykehus og kommune. Målet var å gjøre samhandling på mikronivå mer forløpsorientert, strukturert og mindre personavhengig. Tidlig og fortløpende kontakt skulle skape et bedre grunnlag for å trygge overføringsløp og riktige tjenester på begge sider.

Sykepleiere, ergoterapeuter, leger og ledere fra sykehuset og kommune ble involvert $\mathrm{i}$ utviklingen av de praktiske tiltakene. I tillegg deltok 70 bachelorsstudenter fra sykepleie- og ergoterapeututdanningen ved Høgskolen i Bergen og Haraldsplass diakonale Høgskole i utviklingsarbeidet. Følgende tiltak ble utviklet:

- Sykepleieopplysningskjema fra hjemmesykepleien som skal følge pasient fra hjem til sykehus, eventuelt via legevakt.

- Sjekklister for dialog og vurde- ring av behov; forløpsorienterte og komplementære med hensikt å guide samarbeidet mellom personell i kommuner og sykehus.

- Innreise- og utreisekonvolutten $\mathrm{m} /$ sjekkpunkter.

- Veiviseren «Tryggere hjemreise» som plakat og brosjyre for å stimulere samtalen mellom pasient, pårørende og helsepersonell.

- For å øke sjansen for 
at de nye hjelpemidlene ble tatt i bruk pågikk det parallelt et intensivt arbeid for å integrere dem i EPJ Elektronisk Pasient Journal (EPJ). Det siste viste seg å bli vanskelig i denne fasen. Tiltakene måtte derfor piloteres i papirformat i påvente av å integreres i mer fleksible journalsystemer.

«FRU NILSEN". Ved hjelp av et tenkt pasientforløp vil vi beskrive hvordan hjelpemidlene har vært brukt i den daglige samhandlingen:

"Fru Nilsen" bor hjemme og mottar hjelp fra kommunens hjemmetjenester. Ved besøk søndag morgen registrerer hjemmesykepleier at det har skjedd en endring. Sykepleier henter ut skjemaet «Sykepleieopplysninger fra hjemmesykepleien" fra pasientens hjemmemappe. Hun beskriver avviket fra normaltilstand ved bruk av hjelpepunkter i skjemaet og dokumenterer redusert kognisjon, at pasienten ikke går på egne ben og at hun suetter og fryser vekselvis. Sykepleier mener det er behou for legetilsyn og kontakter legevakten.

DOKUMENTASJON. Skjemaet bistår hjemmesykepleier til å fange opp og beskrive bakgrunns- og tjenesteopplysninger og kliniske endringer hos «Fru Nilsen» på en systematisk måte. Punktene bidrar til å sortere hva som bør observeres og tas stilling til, og til å dokumentere observasjonene. Særlig viktig vil slik dokumentasjon være i tilfeller der pasienten har vansker med å gjøre seg forstått og kommer til legevakten uten følge av pårørende eller hjemmetjenestene. Utfylt skjema legges i den standardiserte konvolutten som er laget for å følge pasienten i det konkrete forløpet. På utsiden av konvolutten krysses det av for hvilken dokumentasjon som er lagt ved.

"Fru Nilsen» har høy feber, er sliten, medtatt og delvis uklar når hun ankommer Akuttmottak ved Haukeland universitetssjukehus, og deretter Medisinsk avdeling samme dag. Medfølgende konvolutt fra hjemmesykepleien med utfyllende opplysninger om hennes normaltilstand sett $i$ forhold til hennes aktuelle tilstand, sammen med innleggelsesskriv fra legevakten, gir audelingen gode nok opplysninger til å igangsette behandling og pleie raskt og på denne måten bidra til trygghet for pasienten: «Her er det noen som vet hva som har skjedd med meg". Pasienten blir utredet nærmere på sykehuset, får behandling for lungebetennelse og blir værende på sykehuset i fire dager.

SJEKKLISTE. Allerede dagen etter innleggelsen tar sykepleier på sykehus kontakt med kommunen for å varsle om at pasienten er innlagt og samtidig starte dialog og samarbeid om videre forløp. Ved at begge parter bruker sjekklistene får man hjelp til å være forberedt og strukturert i samtalen. Sjekklisten retter søkelyset mot pasientens funksjonsnivå før og nå, boligforhold, sosialt nettverk, tiltak og hjelpemidler og pasientens opplevelse av egen sykdom og mestring. Vi har erfart at sjekklisten bidrar til å skape en felles vurderingsplattform da individuelle vurderinger lett kan skape ulikheter i hva som vektlegges og huskes på.

"Fru Nilsen" har ikke hatt hjelpemidler tidligere, men etter samtale med pasient og pårørende kommer det frem at hun i lengre tid har vært plaget med svimmelhet og ved flere anledninger falt og blitt liggende på gulvet. Hun har også strevd med å holde oversikten over medisinene sine. Ut fra disse opplysningene, og hennes nåværende tilstand, henviser avdelingen henne til ergoterapeut for nærmere utredning av hennes funksjonsnivå.

BEDRE BESKRIVELSER. Et tett samarbeid mellom sykepleierne på avdelingen og ergoterapeuttjenesten bidro til bedre beskrivelser av pasienters funksjonsnivå. Legene ble også involvert og pasientens funksjonsnivå ble fast punkt på legevisitt. Man erfarte funksjonsbeskrivelsene som viktige i den videre kommunikasjonen mellom sykehus og kommune, spesielt når individuelle tiltak skulle planlegges og tilpasses.

"Fru Nilsen» ble vurdert av ergoterapeut etter noen dager $i$ avdelingen. I tillegg til en konkret beskrivelse av hennes funksjonsnivå ble det ved hjelp av «mini-mental status evaluering" (MMSE-NR) avdekket betydelig nedsatt korttidshukommelse. Etter avtale sender sykehuset søknad knyttet til hjemmetjenestene om administrering av legemidler. Kommunen sender søk«Sykepleierne nad om ganghjelpemiddel, sørger for koordinerer vanligvis kontakten mellom sykehuset og kommunenes pleie- og omsorgstjeneste.» at det er på plass ved hjemreise og planlegger besøk hjemmet for å vurdere behov for andre hjelpetiltak. Det ble også diskutert behov for korttids plass ved sykehjem, for å kunne observere pasienten over tid og vurdere hennes ressurser og muligheter for å klare seg alene. "Fru Nilsen» ønsker primært å komme direkte hjem. Det vurderes at hun den første tiden vil trenge hjelp til å ivareta sin hy giene, påkledning, ernæringsmessig oppfølging og at hun vil profittere på gjenopptrening av hverdagsfunksjoner $i$ hjemmet (hverdagsrehabilitering).

INNVOLVERING. Brukerperspektivet har stått sentralt i prosjektet, og helt fra starten har man forsøkt å bygge en kultur der åpenhet og involvering av pasienter og pårørende har sin naturlige plass. Veiviseren «Tryggere hjemreise» henvender seg direkte til pasient og pårørende ved å ta opp spørsmålet «hva du bør tenke på før du reiser hjem». Innholdet er utviklet på bakgrunn av intervjuer med pasienter og pårørende før utreise fra 
sykehus, og etter hjemkomst.

De siste punktene på sjekklisten tar for seg forberedelser og praktiske forhold som bør være avklart før utreise: Hvorvidt alle involverte parter er informert om utreisen, informasjon om når første besøk fra hjemmesykepleien er avtalt og om resepter, medisiner og medisinsk forbruksmateriell er ordnet. Videre tar man opp om det er ønskelig at pårørende er med på utreisesamtale, samt praktiske forhold som nøkler til bolig, at pasienten har klær, sko og at det foreligger plan for transporten hjem.

HJEMEISE. Utreisekonvolutten som sendes med pasienter som utskrives fra sykehuset til hjemmesykepleien eller sykehjem, er tenkt som en siste huskeliste med sjekkpunkter på utreisedagen. Den er designet med rubrikker for avkrysning, og har plass til kommentarer. Konvolutten har også felt for avkrysning for om dokumentasjon er sendt elektronisk.

Målet med konvolutten er å kvalitetssikre informasjonsoverføringen, og å synliggjøre avtaler som er gjort mellom sykehus og kommune. Det betyr i praksis å samle relevante dokumenter og materiell som skal følge pasienten ved utreise og kvalitetssikre at dette er utført. Mottaker kan dermed raskt få oversikt på situasjonen. Konvolutten er spesielt nyttig når utreisetidspunktet strekker seg over to vakter. Det blir da lett for sykepleier å se hva dagvakten har utført og hva som gjenstår.

«Fru Nilsen» er nå klar til å reise. Hun er litt oppkavet og spent, men blir roligere når hun hører at sykepleier har informert både datteren og hjemmesykepleien om hjemreisen. Det er også avtalt at hjemmesykepleien kommer på tilsyn i løpet av kvelden. Datter ringer selv sin mor og avtaler å komme hjem til henne tidlig på ettermiddagen. Transporten er bestilt og skal bringe henne helt inn i leiligheten. Utreiseskriv fra legen med oppdatert medikamentliste, resepter, nye medisiner for et par dager og sykepleierapport blir samlet i utreisekonvolutten som «Fru Nilsen» får i hånden. Hun kan da selv lese på konvolutten hva som er utført og «husket på».

EVALUERING. Papirutgavene av sjekklistene og konvoluttene ble pilotert og implementert på tre medisinske poster på Haukeland universitetssjukehus, en bydel i Bergen kommune, samt at Bergen legevakt var involvert. Sjekklistene og konvoluttene ble i 2011 revidert basert på erfaringer med utprøvingen.

Prosjektets to første faser ble evaluert i 2011 og viste at tiltakene hadde bidratt til økt bevisstgjøring omkring innleggelse og utskriving både i kommunen og på sykehuspostene. Likevel var de utviklete skjemaene i varierende grad tatt i bruk blant helsepersonellet. Dette viser at integrering i gjeldende elektroniske pasientjournalsystem er helt nødvendig for at potensialet i hjelpemidlene skal realiseres (12).

VEIEN VIDERE. Erfaringer fra prosjektet er brukt i utarbeidelsen av nye samhandlingsavtaler mellom helseforetaket og tilhørende kommuner og dertil hørende rutiner og verktøy. I sykehuset ble det fra 2012 utviklet en elektronisk variant av sjekklisten fra prosjektet som ble revidert i 2013. Innholdet i sjekklisten er relevant, men formatet begrenser opplevd nytteverdi. Fortsatt er det behov for å finne hensiktsmessige hjelpemidler som i tillegg til sjekkpunkter gir rask oversikt og ivaretar kvaliteten i dialogen. Konvolutten som ble utviklet og som følger pasienten fra sykehuset til kommunen er gjort tilgjengelig for alle sykehusets avdelinger og har vist seg å ha stor nytteverdi for dem som har tatt den i bruk. Den blir fortsatt etterspurt både internt i sykehuset og fra kommuner.

REVIDERT. I kommunen ble sjekklisten revidert i november 2012, og lagt ut på kommunens interne side for elektronisk samhandling, men uten at dette var kombinert med en aktiv implementeringsstrategi. Konvolutten som ble utviklet for bruk i kommunen ble ikke videreført. Skjemaet «sykepleieopplysninger fra hjemmesykepleien» til legevakt eller sykehus er heller ikke implementert aktivt av kommunen, men brukes av noen få bydeler. Kommunen var på dette tidspunktet i gang med implementering av elektronisk meldings utveksling.

ELEKTRONISKE MELDINGER. I 2013 og 2014 har sykehus og kommuner pilotert og innført elektroniske meldinger mellom nivåene. Kontakten som før kun foregikk via telefon, er nå i hovedsak erstattet av elektroniske meldinger. Så langt synes det å tegne seg et bilde av at elektronisk meldingsutveksling har bidratt med en kommunikasjonskanal som er tydelig og der samarbeidspartneren er «tilgjengelig» gjennom etablerte avsender- og mottakeradresser. Bruk av telefon som eneste kommunikasjonskanal var tid- og ressurskrevende. Personell i kommuner og sykehus ønsker seg ikke tilbake til det. Men det er viktig ikke å overse at det fortsatt kan være behov for muntlige faglige drøftinger på tvers av nivåene utover de elektroniske meldingene, for å få avklart status og videre oppfølging. Tilbakemeldinger på bruken av elektroniske meldinger er tydelige på at standardmalene som er tilgjengelige i dag ikke er gode nok. De gir ikke ansatte, verken i kommune eller sykehus, nødvendig guiding for at kvaliteten $\mathrm{i}$ innholdet i overføringen mellom nivåene sikres. Flere av de identifiserte utfordringene fra fase 1 av prosjektet synes fortsatt å være aktuelle. Behovet for verktøy eller maler som er intuitive, med søkeord og strukturert innhold og som bidrar til en faglig veiledning, er dermed fortsatt til stede.

KONKLUSJON. Helsepersonellets faglige rutiner og hjelpemidler kan i seg selv ikke skape trygghet for eldre pasienter som innlegges i sykehus og utskrives til hjemmet eller sykehjem. Like fullt er de viktige for å veilede personellets samhandling i disse sårbare overgangene. Den enkelte helsearbeiders faglige skjønn kan på denne måten i tillegg få støtte og hvile i gode systemer og strukturer. Når slike faglige hjelpemidler utarbeidet på tvers av fag- og forvaltningsnivå, med en intensjon om å gjøre hverandre gode og forankret i pasienters behov, er mulighetene for å lykkes større.

En mer utfyllende versjon av artikkelen med eksempler på tiltakene som beskrives, finnes på sykepleien.no.

\section{REFERANSER:}

. Paulsen B, Romoren TI, Grimsmo A. A collaborative chain out of phase. Int J Integr Care. 2013;13:e008

2. Helleso R, Sorensen L, Lorensen M. Nurses) information management across complex health care organizations. Int J Med Inform. 2005;74(11-12):960-72.

3. Kripalani S, LeFevre F, Phillips CO, Williams MV, Basaviah $\mathrm{P}$, Baker DW. Deficits in communication and information transfer between hospital-based and primary care physicians: implications for patient safety and continuity of care. Jama. 2007;297(8):831-41.

4. Midlov P, Bergkvist A, Bondesson A, Eriksson T, Hoglund P. Medication errors when transferring elderly patients between primary health care and hospital care. Pharm World Sci. 2005;27(2):116-20.

5. NOU 2011:11. Innovasjon i omsorg. Norges offentlige utredninger. Oslo: Statens forvaltningstjeneste. Informasjonsforvaltning; 2011 .

6. Helse- og omsorgsdepartementet. St.meld. nr. 25 (2005-2006) Mestring, muligheter og mening: framtidas omsorgsutfordringer. Oslo: regjeringen; 2006.

7. Helse- og omsorgsdepartementet. Stort.meld. nr. 47 (2008-2009) Samhandlingsreformen: rett behandling - på rett sted - til rett tid. Oslo: regjeringen; 2009.

8. Helse- og omsorgsdepartementet. Nasjonal helse- og omsorgsplan: 2011-2015. Oslo: regjeringen; 2011.

9. Helse- og omsorgsdepartementet. St.meld. 29 (20122013) Morgendagens omsorg. Oslo: regjeringen; 2013.

10. Helse- og omsorgsdepartementet. Fremtidens primærhelsetjeneste: nærhet og helhet. Meld. St. 26 2014-15, Oslo: regjeringen; 2015.

11. Danielsen B, Fjær S. Erfaringer med å overföre syke eldre pasienter fra sykehus til kommune. Sykepleien Forskning. 2010;5(1):28-35.

12. Førland O. Evaluering av prosjektet «Trygg overføring»: et samhandlingsprosjekt om inn- og utskriving av eldre pasienter mellom sykehus og kommunale hjemmetjenester. Senter for omsorgsforsking Vest, 2011.

\section{FAGARTIKLER:}

Fagartikler kan sendes til torhild.apall@sykepleien.no 